

\section{Notice}

This report wa prepered an account of work aponored by the Untied Steter Gowemment. Nather tha Unined Staves hor the Ualtod Staten Enery Resingch - Devalopment Adriikjuntion, nor my of thelr employest, nor eny of theit contrections, subcontractori, or thit employet, maker any wirrinly, exprea or

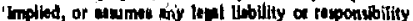

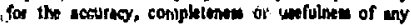
informution, oppuratus, product of procen diclukd, of reprements thite, His use would not insting prevatelyowned rithty.

\section{NOTICE}

Reforence to a onginy or produst name does not imply eppraval of recommendation of the product by the Untwerdity of Californils on the U.S. Enetgy Resurch

(i) Development Adminiotution to the excluaton of others that mry be witsole.

Printed in the Untied States of America

$\therefore \quad$ National Technical Information Service

U.S. Departmest of Commetce

5285 Port Roya: Road

Springficld, VA 22161

Price: Psinted Copy $\mathbf{5}$; Mierofiche $\mathbf{5 3 . 0 0}$

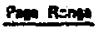

Domatis

$001-025$

Price

\begin{tabular}{l} 
P $R=100$ \\
\hline $326-350$ \\
$351-375$ \\
$376-400$ \\
$401-425$ \\
$426-450$ \\
$451-475$ \\
$476-500$ \\
$501-525$ \\
$526-550$ \\
$551-575$ \\
$576-600$ \\
$501-4 p$
\end{tabular}

Dometle

026-050

$\$ 3.50$

4.00

4.50

5.00

076-100

$$
5.50
$$

6.00

126-150

151-175

176.200

6.75

7.50

7.75

8.00

226--50

251-275

276-300

9.00

.9 .25

$301-325$

9.75

*Add 3250 for ech siditional 100 pago inerement from 601 to 1.000 pering;

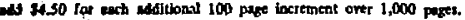




\section{[Lب \\ LAWPENCE LJEPMORE LABORATORY}

iniversily of Caifornia Livermore, Calitomia 94550

UCRL-52117

\section{HOT SPOT EXERCISE-1975 (HSX-75)}
R. T. Trolan
R. L. Wilson
F. W. Jessen

MS. date: August 23, 1976

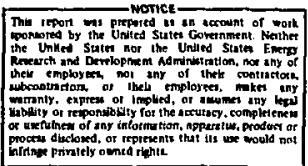




\section{Contents}

Introduction . . . . . . . . . . . . . . . . . . . . 1

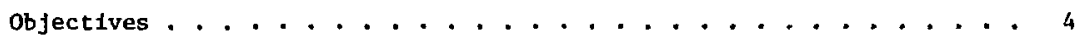

Exercise Control and Limitations . . . . . . . . . . . . . . . 4

Scenarto . . . . . . . . . . . . . . . . . . . . . 8

Alert Center Operations . . . . . . . . . . . . . . . . . 11

HOT SPOT Teum Organization . . . . . . . . . . . . . . . . . . 11

Site 300 Operation... . . . . . . . . . . . . . . . . . 12

Appendix A. Operational Safety Procedure . . . . . . . . . . . . . 14

Appendix B. Photographs and Site Map . . . . . . . . . . . . 16

Appendix C. HOT SFOT Equipment . . . . . . . . . . . . . . . . 22

Appendix D. Atmospheric Re] ease Adrlsory lapabllity (ARAC) . . . . . 27

Appendix E. Personnel list . . . . . . . . . . . . . . . . . . 31

Appendix F. Chronology of Events . . . . . . . . . . . . . . . 34

Appendix G. Critique Comments . . . . . . . . . . . . . . . . 38 


\section{HOT SPOT EXERCISE-1975 (HSX-75)}

\section{Introduction}

Lawrence Liverinore Laboratory (LLL), In response to requirements from the U.S. Energy Research and Development Administration (USERDA), maintains a continuing capability to respond to nuclear weapon accidente or incidents upon authorization from the Assistant Administrator for National Security (AANS). The ERDA responstbilitles are defined in ERDA Manual Chapter 0527, and are orlented toward providing technical support and expertise to the Department of Defense (DOD) upon formal request according to a joint agreement revised in 1970. The Joint Chiefs of Staff (JCS) will formally notify the Division of Military Application (DMA), ERDA Headquarters, that a nuclear weapon accident or Incident has occilied. Subsequently, the Director, DMA, with the approval of the AANS, will arrange $f u r$ the formation and dispatch of an ERDA Accident Response Group (ERDA/ARG) with the necessary specialized equipment via milftary or commercial transportallon. If the accldent is a Broken Arrow Involving an LLL designed weapon, the ERDA/ARG in all probability w1ll include the LLL HOT SPOT Tean equipped with the mobile counting laboratory (Trailer
113) and dicontamination facility ('Irailer 1.14). The HOT SPOT Team will suppor: the DOD under the direction ot: the on-scene ERDA representidt lve and the LLL Sentor Sclentifir: Advisor. The FRDA/ARG is structured in this manrer to provide the best utilization of the technical expertise of each Individual and the design capability of specialized equipment .

A spectal unannounced exercise, called HOT SPOT Exercise - 1975 (HSX-75), was prepared to test the general capabllity of the LLL ALERT Program to activate and deploy the LLL and Sandia Laboratory, LIveimore (SLL) component of the ERDA/ARG. The exercise activities were limited to the LLL factlities in Livermore and the Site 300 explosive test facility located approximat fiy 15 miles southeast of Livermore. The exercise simulated an accldent at a U.S. Army storage facility (Site 300). The sluulated accicient involved two LLL designed weapons $(W-70)$. One weapon was dropped during unloading operations and 1gnited the gas tank of the weapon transporter. The subsequent fire caused a low-order detonation of the high explosive 
component. The fire caused dispersal of fissile material downrind from the site. A second weapon was damaged i:a the expjoston by fragments from the first weapon. The extent of damage to the second waapon was initially unknown.

The exercise was intitited through the LLL Police Communications Center. The imrediate notification of a LLL Sentor Scientific Advisor (SSA) and his initial actions develuped essential information on which to evaluate the requirement for selection of the approprlate HOT SPOT Team members and equipment. This informition was provided by an ERDA representative (played by an LLL staff membei). The Army's 34 th EOD Team was actually deployed to the exercise site in advance to better simulate a normal Intitial accident response. An officer from the Defense Nuclear Agency (DNA) group at LLL portrayed the role of the On-scene Military Commander (Major General). These personnel constituted the milltary structure to which the ARG provided support. FIgure 1 shows the ERDA/ARG organization and those players who fulfilled speciflc functions.
Exercise guldelines were established uttlizing the following references:

1. Lawrence Livermore Laboratory Alert Emergenity Response Plan.

2. AEC Manual. Appendix 0527 "AEC Response to Accidents Involving Nuclear Weapons in the Custody of the DOD" (Handbook), February 15. 1972 .

- Part I Introduction

- Part II Standard Operating Procedures

- Part III AEC Accident Response Group Organization and Duties

- Part IV AEC/ARG Roster of Qualified Personnel

3. AL Chapter 0527 "AEC Response to Accidents Involving Nuclear Weapons in Custody of the DOD," August 14, 1972.

The exercise was conducted on September 23, 1975. A complete description of the specific nature of the simulated accident is contained in the scenar1o. Umpires were assigned to evaluate and subsequently report on the effectiveness of the response (Appendix G), All test objectives were accomplished. 


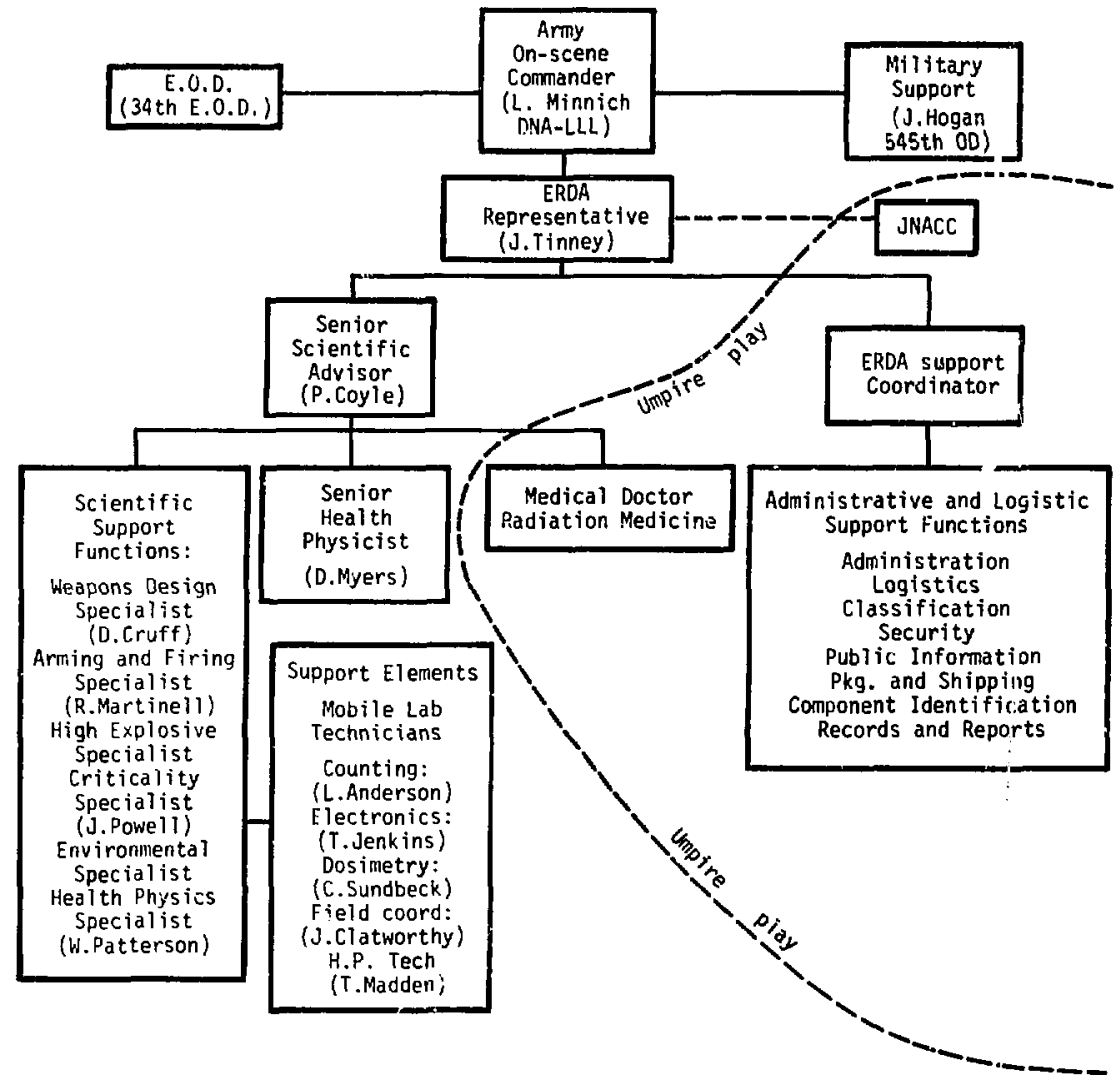

Fig. 1. ERDA/ARG organization. 


\section{Objectives}

- Cneck the LLL cperational procedures and guides for adequacy in accordance with existing ERDA plans. Additionally, the exercise presented an opportunity to interface with DOD elements (EOD) under simulated accident conditions. Test the effectiveness of the LLL Polfce Communf.cations Center and LLL Emergency DIspatcher (Fire Department) to inftiate proper communications procedures which enabled the prompt activation of the LLL/ SLL components of the ARG and other support organizations requested by the SSA.
- Test the response readiness of the LLL/SLL components of the ERDA/ARG, including the HOT SPOT equipment.

- Conduct a serviceabilfty check under emergency field conditions of the instrumentation and stored equipment on the mobile counting laboratory (Trafler 113) and mobile decontamination facility (Trailer 114).

- Permit an evaluation of the effectiveness of the LLL Atmospheric Release Advisory Capability to support ARG field operations.

\section{Exercise Control and Limitations}

Alert personnel and members of the LLL/SLL ARG components with primary duties Involving contact with factlities other than LLL were advised prior to the exercise to simulate their inputs (i.e., make no actual contact with any person or agency outside LLI). Inputs of information and/or requests to outside agencles, etc., were made to umpire personnel at Laboratory extension 3974 or 3854 .

Personnel participating in the succession of telephone calls necessary to accomplish team activation were instructed to first advise the person contacted that "THIS IS AN EXERCISE," and thereafter requested response in accordance with preplanned procedures. Each person was requested to indicate to the person contacted that the exercise was $11 m i$ ted to LLL and SLL particlpation only.

ALERT personnel and ARG Team members were expected to respond according to the guides set forth in the LLL ALERT Procedure. 
Travel packets were checked and issued (simulated) by Business Services at the ALERT Center, Room 170, Building 111. HOT SPOT Team members responsible for the activation of Trailers 113 and 114 were required to complete all preparations necessary for departure of Travis Atr force Base. When the preparations were completed, selected tean merbers were instructed to transport both trailers to an offsite simulated accident area, Building 836, Site 300. Maps were provided.

HOT SPOT Team members responsible for setting up Trailers 113 and 114 were required to do so upon arrival at the simulated accident site. Use of portable generators was required. Contaminated samples were provided sind appropriate analysis was made. A cherk for serviceabiitity was made of vehicular apparatus, service equipment and specialized instruments.

ARG members were required to use transportation modes consistent with what would be used in an actual emergency .

The exercise umplre group controlled the course of the exercise by providing information to the players from time to time. The Sentor Exercise Umplre terminated the exercise when test objectives were completed. All umplre check lists and exercise critique lists were collected and collated by the $S$ entor Umpire.

A critlque of the operation was held at 1315 hours, September 24, 1975, in Room 170, Building 111.

A final report was provided to the LLL Associate Director for Nuclear Explosives and the LLL Plant Manager 30 days after completion of the exercise. 
PLANNED SCHEDULE OF EVEN:S

TIME

0730

0735

$0 \dddot{745}$

0830

0830-0900

0930

1030
EVENT

Initlate exercise. Call made to

Polfce Communications Center by

George Mackanic.

SSA identifled; put in contact with

ERDA representative (simulated)

played by $G$. Mackanic.

SSA tells Police Communications

Center to (1) activate HOT SPOT Team,

SLL representative, ARAC;

(2) activate

ALERT Center, identify key

personnel to meet SSA there ASAP.

Army EOD Team at Site 300 starts

response tc accident situation.

Assemble HOT SPOT key personnel;

brief on accident; coordinate

operations.

Dispatch HOT SPOT inilial and

follow-on team to site 300 .

(1) InitiaJ. HOT SPOT Team arzives

on-site Bldg. 836, Site 300 and is briefed by Army on-scene Commander and ERDA on-scene coordinator (2) Weapons Design Engineer and Arming. Fusing and Firing Specialists begin operations with Army EOD Team.

Follow-un HOT SPOT Team with trailers arrive at Bufluing 836 and set up for field operations.
PERSONNEL

Police Comminications

Cert ar personnel.

SSA

SSA, Police Communications

Center, Health Phystcs,

Weapons Designer, Fleld

Coordinator, SLL representative, Business Services, ARAC.

34th LOD Team and Umpires.

SSA/ALERT Center r,oordinator.

SSA, SHP, Weapons Designer, $A F$ and $F$ (SLL representa(ive), etc. 
1200-1300 Lunch at Site 300 for exercise

personnel. Rotate operational.

crews.

1300-1530 Site Operations

All field personnel.

- Health Physics (HOT SPOT)

- EOD Operations (LLL/SLL)

- Senior Scientific suvisor

1530 Terminate ex arcise. All field personnel.

1530-1630 Secure equipment and return

exercise personnel to Livermore.

NOTE: Critique of the Exercise HSX-75 will be in Room 170, Buflding 111 at 1315 on the day following the exerctse.

$1315 \quad$ Opening remarks.

1330-1400 Review of the exercise*

- Initial operaiton

(1) Communications SSA will muderate.

(2) ALERT Center

- Field operations

Fleld SSA will moderace.

(1) Command and coordination

(2) Health Physics operations

(3) EOD operations

1530-1545 LLL Management cbservations.

Senior Scientific Advisor will moderate with input from the senior representative from each maior working group (1.e., Weapons Design, Senior bisalth Physics, $\triangle F$ and $F$ (SLL), appropriate umpire personnel). 


\section{Scenario}

Simulated Location: Army Ordinance Depot

Actual Location: Site 300

Time 0630 hours, 23 September 1975

Winds: Attual at Site 300

Problem:

Two $\mathrm{W}-70$ warheads arrived at an Army depot (Site 300) during the early morning hours. They were taken immediately to the storage bunker adjoining Building 836. Two forklift crews met the weapons transporter and started unloading operations. The first $W-70$ (Weapon A) was removed from the transporter and set to one side of the entrance to the bunker. The second forklift. immediately proceeded to remove the second weapon (Weapon $B$ ). As Weapon $B$ was lifted from the transporter the forklift hydraulic mechauism falled, dropplng the weapon container against the gas tank of the transporzer. The gas tank exploded in Elames. The resultant fire caused the high explosive to partially burn and to detonate loworder. The smoke cloud, which contained fissile material, was carried downind and of the milltary reservation.

Firefighters at the Army depot were immediately dispatched to the scene and contalned the fire, finally putting th out after about 30 minutes. F1refighters removed the bodies of four workers killed in the blast. Five other persons were taken to the base dispensary. (No action was required of HOT SPOT Team members).

The Army's 34th EOD detachment located at the depot immediately moved into the accidenc site and cordoned of $f$ the danger area. They were dressed out in full anticontamination gear. Their first task was to clear a path through the unexploded high explosive to Weapon A which still remalned by the bunker entrance. The container was crushed to some extent by the low-order detonation of Weapon $B$, but the degree of damage to Weapon A was unknown at this time.

The depot Commander immediately notified his Sector Commander by telephone that a Broken Arrow had occurred at the installation. The Sector Commander, in accordance with the Sixth Army Nuclear Accider.t/ Incident Control Plan, infurmed the Heallquarters, Sixth Army, at the Presidio of San Francisco, and requested assistance. This requese. was passed through military channels to the Joint Chiefs of Staff and 
thence to the ERDA Emergency Operations Center (EOC). Simultaneous calls went from the EOC to JNACC and to the LLL Police Communfations Center.

MESSAGE 1. The text of the message tranamitted to the LLL Police Communications Center is as follows:

THIS IS AN T.LL HOT SPOT EXERCISE. 1 repeat. THIS IS AN LLL HUT SPOT EXERCISE. A "Broken Arrow" has orcurred at an Army depot. Please put mo in contact Immediately with a Senior Sclentific Advfsor. This is a simulated emergency."

MESSAGE 2." Message from the ERDA EOC to the Senlor Scientific Advisor.

"THIS IS AN LLL HOT SPOT EXERCISE. I repeat. THIS IS AN LLL HOT SPOT EXERCISE."

\footnotetext{
The caller should present enough information and establish the urgency such that the Senior Scientific Advisor will immedlately contact the Police Communications Center to:
}

1. Activate the ALERT Center, Room 170, Building 111.

2. Contilct key people to meet in the ALERT Center.

3. Call the Emergency Dispatcher at the Fire Department to start activation of the HOT SPOT Team and the ARAC.
For administrative purposes, this exercise has been prepared to test the response of the LLL and Sandia Laboratory Component of the ERDA Accident Response Group, and is IImited to LLL and SLL personnel only. You are not to lnvolve any person or agency outside of LLL and SLL. To make any simulatad outaide calls, contact Umpire: Control at the Laboratory, Ext, 3974. These administrative ingtrutions are also being given to the Polfce Communications Center and the Emergency Dispatcher.

The exercise message is: "I am calling from the ERDA EOC. The JCS has just informed us that a Broken Arrow has occurred at an Army depot. We believe this involves a W-70 or several W-70's, We are attempting to get more information. It appears to be a pretty bad scene. General Bratton has asked us to alert y su so that you can get the HOT SPOT Team ready, We or JNACC will pass more detailed information to you as soon as it is recelved."

MESS IGE 3. To be used by the Emergency Dispatcher in alerting HOT SPOT Team members and ARAC personnel.

RADIO PAGE

"THIS IS TO ADVISE YOU THAT AN LIL HOT SPOT EXERCISE HAS BEEN CALLED. 
THIS IS A HOT SPOT EXERCISE. Please report immediately to your ALERT station. Do not contact persons outside of LLL or SLL. Respond as you would in an actual incldent. Thank you."

\section{TELEPHONE}

Same as above.

MESSAGE 4. Call frum the Pollce Communications Center to ALERT

Committee members.

\section{RADIO PAGE}

"THIS IS TO ADVISE YOU THAT AN LLL HOT SPOT EXERCISE HAS BEEN CALLED. THIS IS A HOT SPOT EXERCISE. The Sentor Scientific Advisor has asked that you report immediately to the ALERT Center, Room 170, Bullding 111 at the Jaboratory. Do not contact persons outside of .LL or SLL. This is an exercise. Thank you."

\section{TELEPHONE}

Same as above.

MESSAGE 5. Call from General Bratton in the EOC to LLL, SSA (to be called to the SSA in the ALERT Center).

\section{EXERCISE MESSAGE}

"Say PhIl, we have some additional Information regarding tito: Broken Arrow. One of the $\mathrm{W}-70^{\prime} \mathrm{s}$ was involved in a fire which caused an explosion.
The base Fire Department put out the fire; however, we can presume that some of the fissile tnaterial was carried dorynwind in the smoke cloud. It may have gone off the reservation. Can your ARAC people help us on that? Take a worse case on the parameters. The Army EOD is trying to get a second weapon which is apparently damaged. Hopefully they will have established some radlologica] control on the area, or we'll have the entire base contaminated. There were some casualties, apparently three or four people killed, a half dozen or so have been taken to the base dispensary.

I have JNACC clecking out the alrlift from Travis to the accident site for you. They'll be giving you a call before long. How long would it take you to Arive up there? Perhaps you can get a chopper from the Presidio to plck up your advance party. When will they be ready? When wtll your HOT SPOT mobtle equipment be ready? They could start for Sacramentci as soon as they're ready and if we can get alrlift they can go rigit in at Travis. I think this will be the case, if nor, they're that much further along. EXERCISE OUT."

MESSAGE 6. JNACC to SSA in ALERT Center. 
EXERCISE MESSAGE

"This is Dave Foster at JNACC. I've got a tall number for you on a C.-141: No. 94526. They're at Travis now, and will depart as soon as you arrive. An escort will meet you at the gate. Your contact is Col. Brown, Ext. 3974. Please give him and us your ETA at Travis as soon as known. Walt wh lte is on his way to the accident site by commercial air. He has been designated the ERDA Coordinator. EXERCISE OUT."

\section{Alert Center Operatious}

When the ALERT Center is activated and the key personnel are present, the Senior Scientific Advisor can develop his plan and brief the key members of his group on the operation and reseive recommendations frou them. These discussions should include:

- Health Physics problem associated with the, $:$ ned fissile material in the $W-70$.

- The plans of the $\mathrm{W}-70$ for the weapons designer to take with him. Special tools or equipment required.

- Transfortation to the site via Travis, airlift or accual road narch. The necessity for police escort. Check with the Sixth Army Accident/Incident
Control Center (NAICC) for chopper to airlift advance party to the accident site.

- Business Services check and issue of the travel packets.

- Designation of the Field Senior Scientific Advisor and advance party members.

- Request. for information as to the name of the military base comnander, ERDA on-scene coordinator; rendezvous location and arrival instructions.

- Strip maps and identification of routes.

- Conmunications requirements from the Laboratory to the accident site.

\section{HOT SPOT Team Organization}

The Senior Health Physicist will be in charge of the Hazards Control Department's component of the HOT SPOT Team in the field. When alerted, he will report to Room 1508, Building
253, unless otherwise instructed, and set up his command post. He will then call the SSA of the status of his team mobilization efforts and receive any instructions. 
As team members arrive, he will select the personnel to accompany him to the field. Those in charge of the mobile laboratory and decontamination units will check the condition of the untts for deployment. To Insure safety when deploying, there is a short check 11st in the Hazards Control HOT SPOT Book which should be completed.
Arrangements should be made to obtain two LLL professional truck drivers to drive the trucks. These arrangements should be coordinated through the ALERT Center. One tean member will be assigned to acrompany each truck. Other HOT SPOT Team members can be transported by Government vehicles. Travel packets should be obtalned for personnel ieploying with the team.

\section{Site 300 Operation}

The advance party from LLL arrives at the Army Depot (Site 300) by helicopter (automobile) at approximately 1030 hours. Members of this team include as a minfmum the Senior Scientific Advisor, a Senior Health Physicist, a Weapons Designer, and an Army Fusing and Firing Specialist (SLL). Contact is immediately made with the Depot Commander and the ERDA On-scene Coordinator. They are briefed by the CO of the 34 th EOD detachment regarding the situation.

The situation has stabilized considerably. An exclusion area has been established around the contaminated area. The suspect areas off-site have been sealed off by the Highway Patrol and Military Police. A Hot Line has been established upwind at the gate to the fenced-in area in which the bunker is located. Only the Depot Cormander can authorize limited access beyond the fenced area. Radio commulication is being maintained with EOD personnel in the excluston area. EOD personnel are experiencing some difficulty in rendering safe the damaged weapon. Assistance is requested from the LLL Weapons Designer and the SLL Arming Fusing and Firing Specialist. These individuals dress out and proceed Into the exclusion area. Pathways have been cleared through the unexploded H.E. to the damaged weapon. The Depot Commander requests advice from the SSA and SHP on fixing the contamination temporarily. filso, the Commander requests advice on handling the patients at the base dispensary to avold further contamination. However, the SHP is not required to go to the dispensary. The SHP discusses an appropriate location for the Decon facility and the 
Counting Laboratory. It appears that the parking area in front of Building 836 is adequate for space and upwind of any anticipated problem. Water is avallable in the parking lot for the Decon Trailer, at a sultable location next to the Hot line. Electrical power will have to be run from the generator truck unt 11 power is ristored to the area.

When the HOT SPOT Teain arrives, they will place the vehicles and trallers as directed by the SHP and set up for operations. Their decon set-up should be completely integrated into the Hot Line operation established by the Army.

Team members will be dispatched to take soll samples. The data obtained from analysis of the samples should be compared/correlated with the ARAC Information which is forthcoming from livermore. When this information is received, recommendations will be made by the SSA to the ERDA Coordinator and Depot Commander regarding the significance of the levels as they affect health and safety.

The Depot Commander should solicit information and advice regarding the reduction of the exclusion area, proteclion equipment required in the exclusion area, cleanup processes neceseary to restore the site area (asphalt and sol1) to background radiation levels, and decon of equipment in the area. Advice should also be sought about releasing the ared sealed by the Highway Patrol. Coordination will be required wit'. ERDA for the shipment of weapons components recovered to some other locations; also shipment of the damaged veapon for renovation or disassembly. Arrangements will have to be made for disposition of contaminated soll, asphalt and water. When enough information has been developed or action has been taken by the HOT SPOT Team nembers to make a judgment that the accident-related problems have been resolved or are sufficlently understood to permit a realistic resolution, the exerctse will be terminated by the Senfor Exercise Umpire. Upon termination, the equipment w111 be secured in the trailers and the HOT SPOT Team and mobile equipment will be returned to Livermare. 
Appendix A

Operational Safety Procedure 
LAWRENCE LIVERMORE LABORATORY

Operatimal Safes. Procedure

Vo._. 836-750915

Effective: $-9 / 15 / 75$

IITLE: HOT SPOT Exercise - 1975 (HSX-75)

Expires:

$10 / 1 / 75$

Acct. No.:

INTRODUCTION:

Reason for Isste: Site 300 Procedure 121 requires that an OSP be written when fissile materiat is used on-site (i.e., Pu, Oy, etc.)

Hozards Analysis: < 1 gram of Pu-239 < 1 gram of Oy will be mixed with soil to proxide

realistic samples for analys is at the exercise site. Should the material be sollled it

witl contaminate a small area of the exercise site. Personnel in the exercise wili be

equipped with respirators so there are no health problems - only the inconven ience of cleanup.

However, all samples will be double encapsulated in plastic. The samples will then be

placed in metal sample containers at specific locations on the ground. Samples will be in

SCOP: a controlled area at an times. At no time will the samples be opened at site 300.

Location: Bldg. Bldg. 836 outside area and BIdo. 822

Range of work authorlzed: Have samples made at Building 332 , transponted to Site 300 by liaterials

Management, used at the exercise site for counting and analyses during the exercise.

At the completion of the exercise the samples will be returned to 31 dg. $^{3} 32$ at Livermore.

RESPONSIBILITIES:

M. H. Chew

is responsible for the safety of this operation and observance

of all Laboratory safety guides: his alternate is

R. T. Trolan

MATERIAL CONTROLS:

$\frac{\text { Statenal }}{\mathrm{Pu}-239 \text { in soil }}+\frac{\text { Ampe }}{1 \mathrm{gm}} \quad \frac{\text { Storage }}{\mathrm{B}-822 \text { (overnight) }}$

oy in soit

$<1 \mathrm{gm}$

B-822 (o:'ernight)

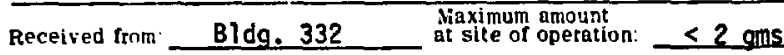

Removed to: Site 300

Criticality safety: 2he unit desctibed is as signed a Type N/A_Criticallty Hazard (Ref.

OPERATING \& PERSONNEL CONTROLS

1. Samples will be made up in Bidg. 332 and doubly encapsulated.

2. Samples will be picked up at 81 idg. 332 and transported to Site 300 by Materials

Management the day prior to the exercise.

3. The Site 300 Health \& Safety Tech wiji receive and swipe the samples prior to releasing

the samples to the Umpire Group Heal th Physicist.

4. Th: samples will be placed at appropriate exercise locations by the Umpire Health Physicist

5. Samples will be in a controlled area or in the custody of a Health Physicist throughout the duration of the exercise.

6. At the completion of the exercise, the samples will be returned by the Umpire Health

Physicist to the Site 300 Process Area Coordinator for movement back to Bldg. 332 by

Materials Management.

Distribution:

R. Trotan

in. Chew

J. Dittig

R. Guarienti (2)

J. Olsen

J. Tinney

C. L. Meadors

W. C. Conner

R. K. Mullins

W. M. Dougan

1. $2: 24$ H. $1.3 . ?$
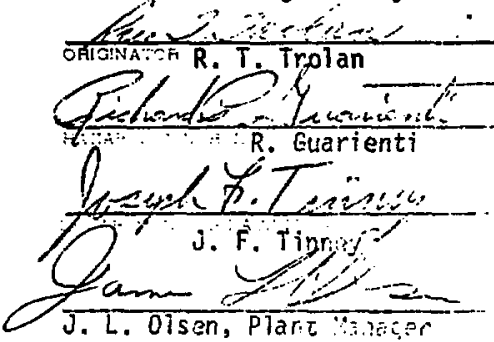


\section{Appendix B \\ Photographs and Site Map}




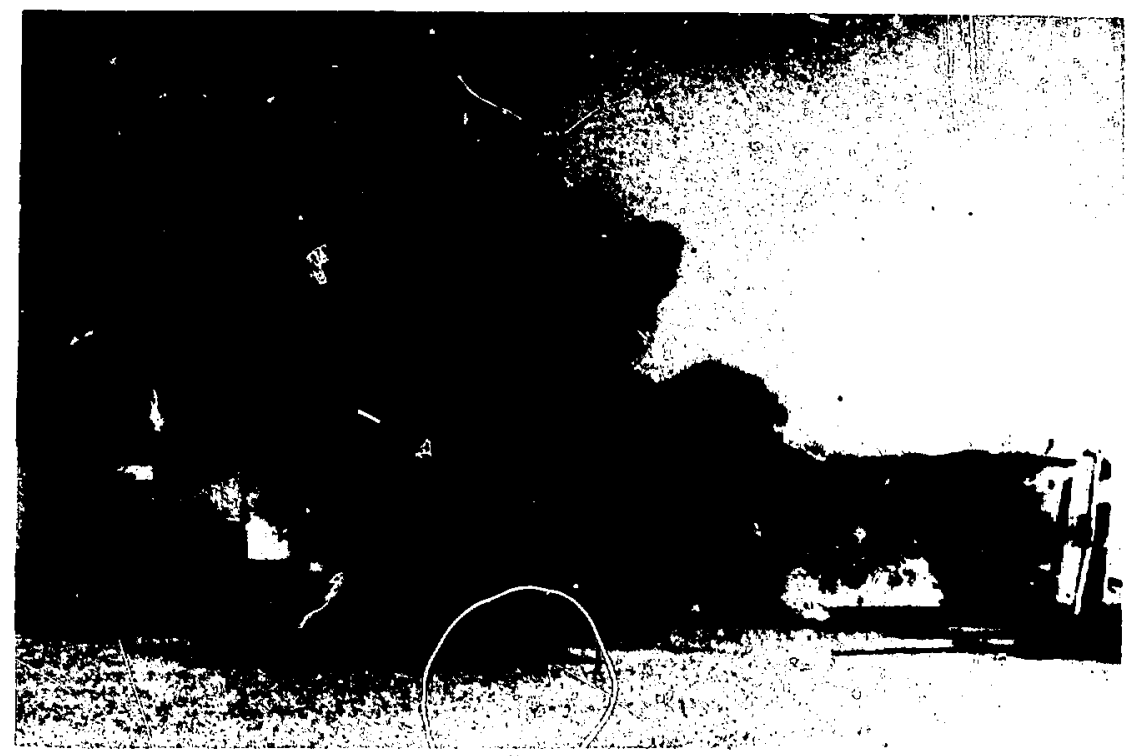

Fig. B-1. "Staged" vinicle accident and fire.

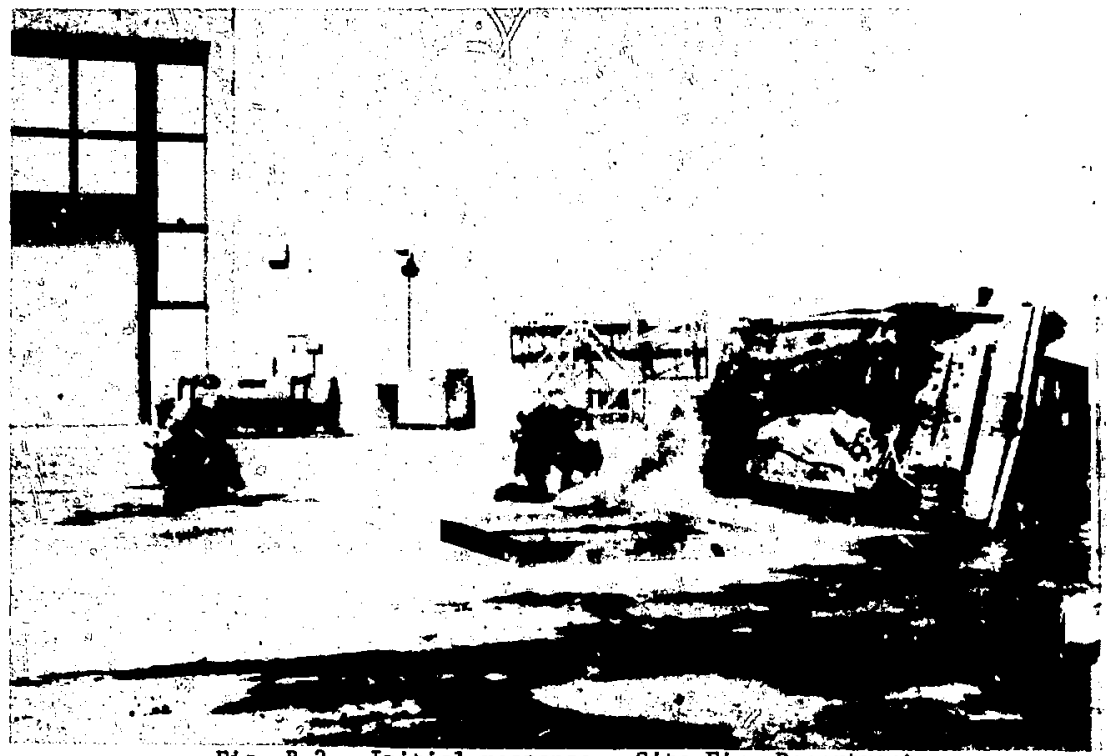

Fig. B-2. Initial response - Site Fire Department. 

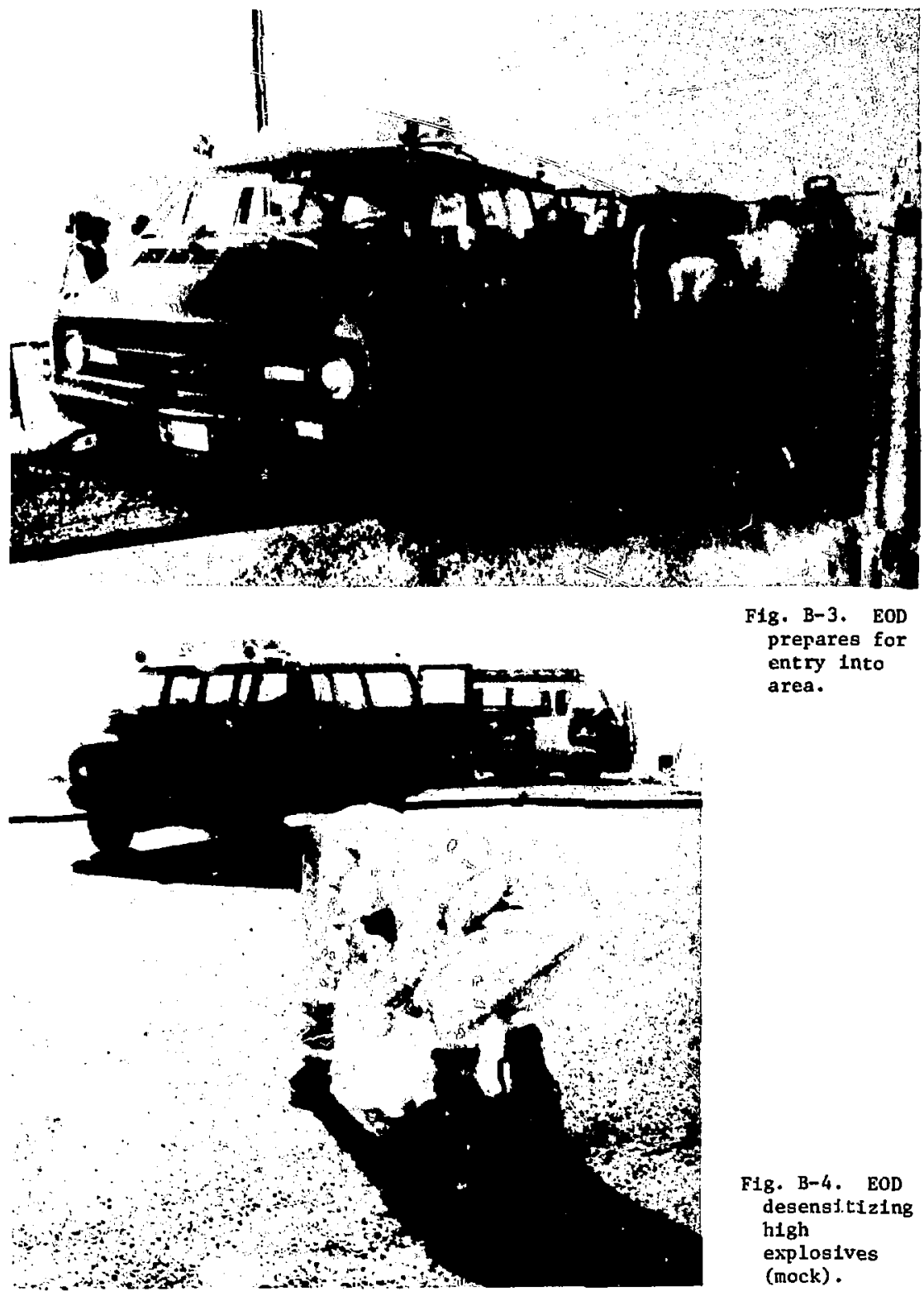

Fig. B-3, EOD prepares for entry Into area.

Fig. B-4. EOD desenstitizing high explosives (mock). 


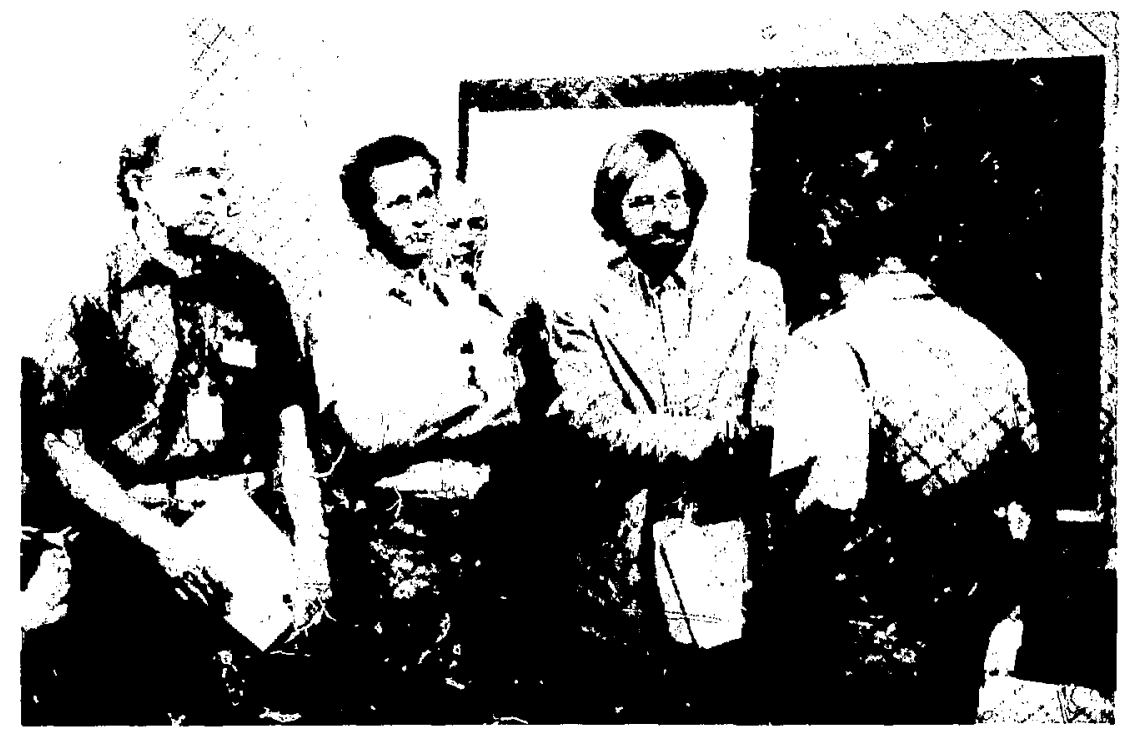

Fig, B-5. Inttlal brlefing of the HOT SPOT Team,

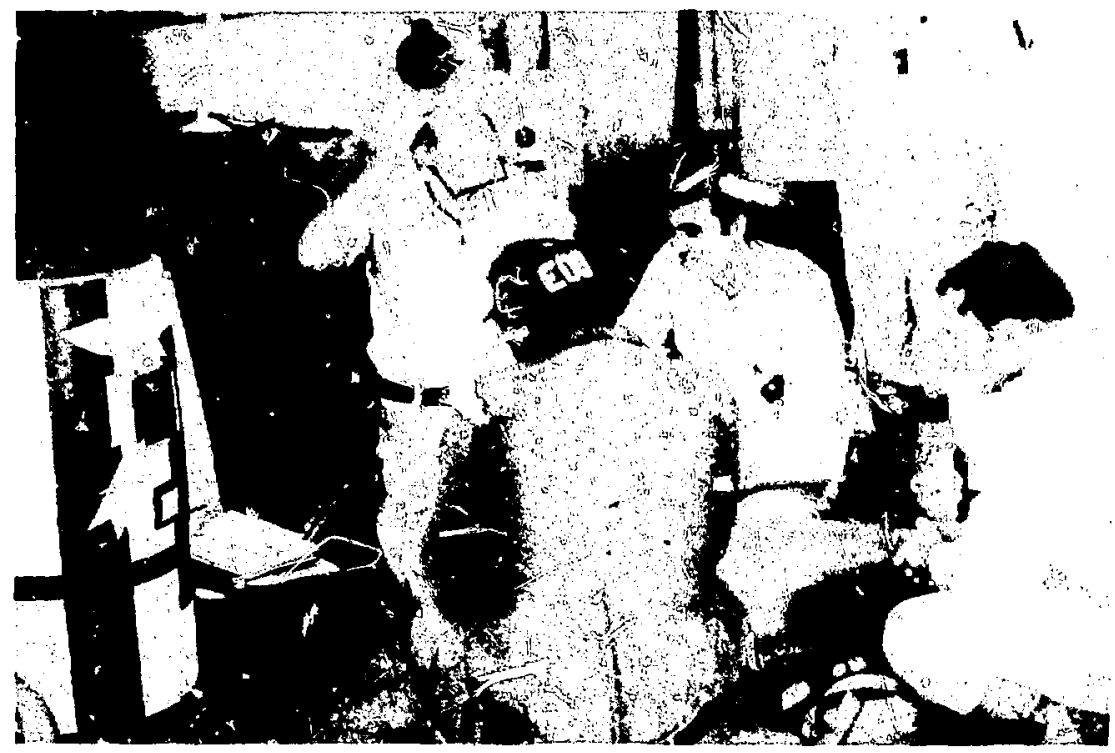

Fig. B-6. EOD and HOT SPOT advisors conferring. 


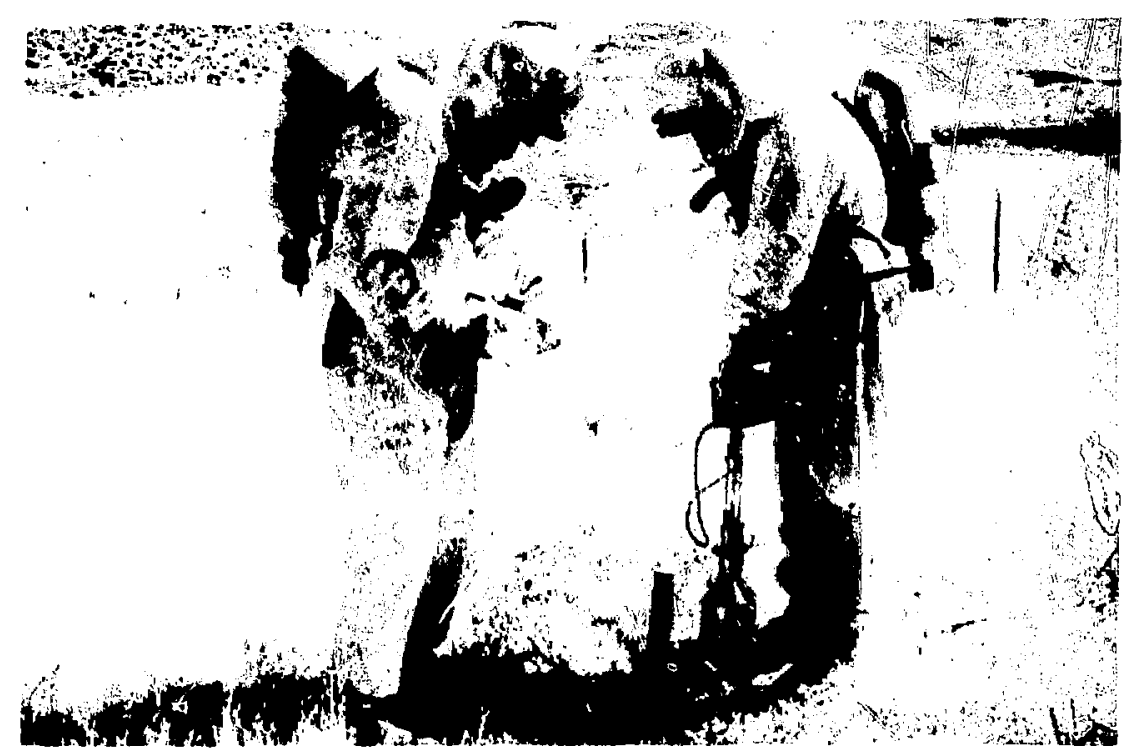

Fig. B-7. Radiation survey team.

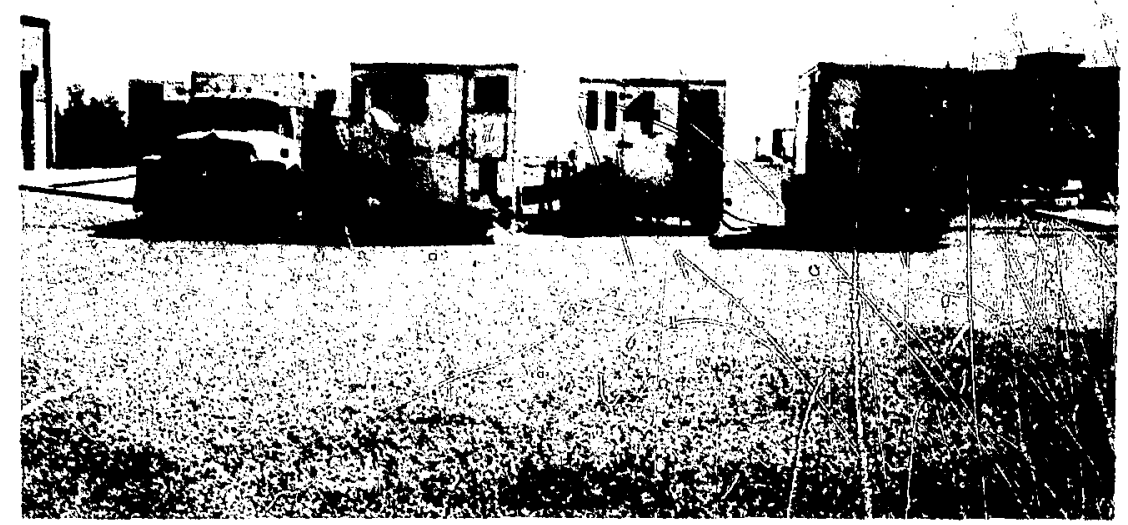

Fig. B-8. НОт SPот mobile laboratory and decontamingtion unit. 


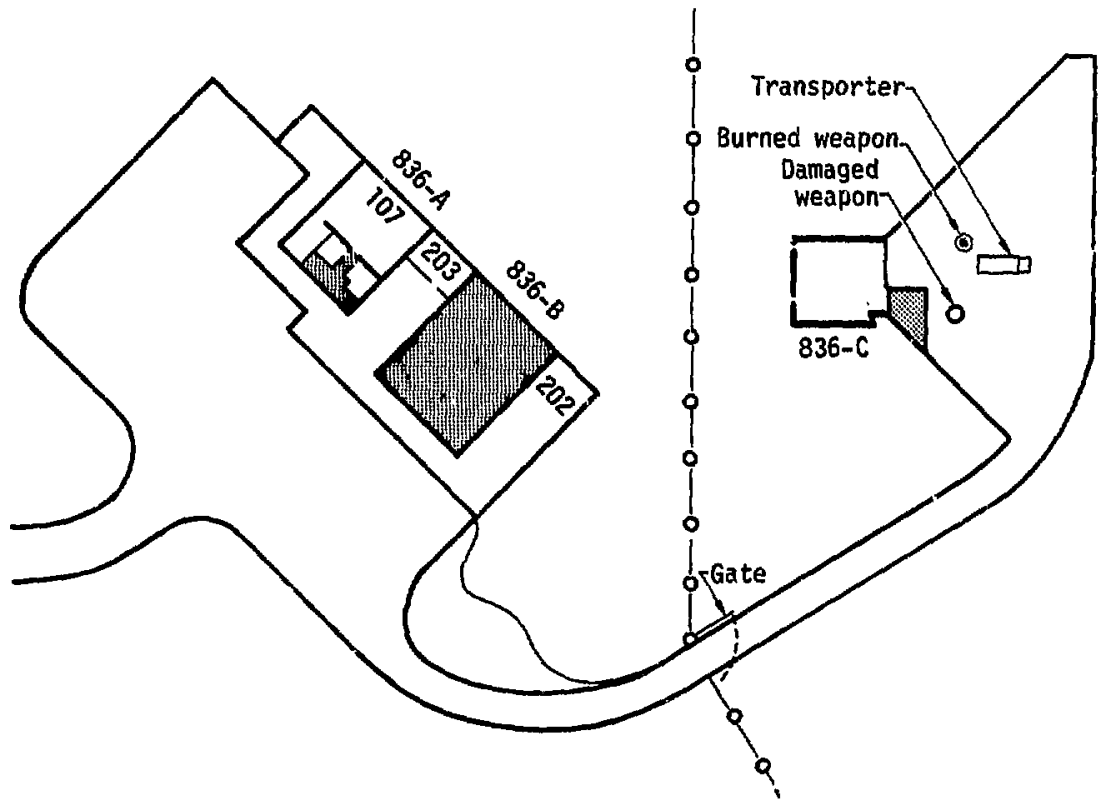

Fig. B-9. Site map.

$-22-$ 
Appendix C

HOT SPOT Equipment 
In accordance with agreements between the ERDA and the DOD, LLL inaintains a "HOT SPOT" team of specialists on continuous alert to provide assistance to the DOD in accidents Involving nuclear weapons. The Hazards Control portion of this team consists of Senfor Health Physicists, Criticality Specialists, Radiation Counting Specialists, and Electronic Specialists. A wide varlety of equipment is kept in constant readiness to provide the necessary tools to the team in the fleld to find, Identify, and control radioactive contamination at an accident scene. All of the equipment is kept in two trucks and two trailers which make up the HOT SPOT Mobile Laboratory (F1g, C-1).

The HOT SPOT Mohile Laboratory is designed to be a completely selfoperating unit, requiring only replenishment of fuel and water supplies. The Generator Truck carries the equipment to provide heating, cooling, ventilation and elactrical power to the other units; the truck also tows a Counting Trailer. The Counting Traller is a rather completely equipped radiation counting and

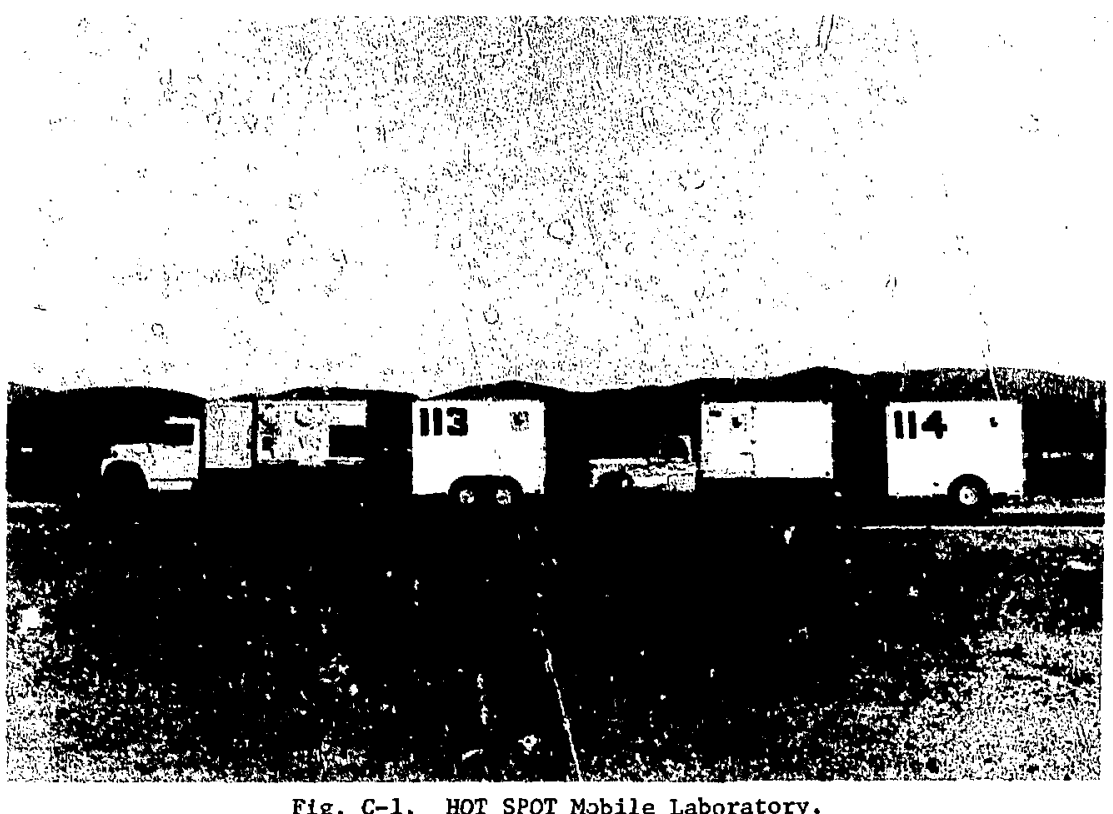


analysis laboratory. Installed in it is the equipment necessary to do alpha, beta and gamna counting. The major systems consist of a sulti-channel analyzer with a 75-X 75-mm NaI crystal detector in a shield, a gas flow proportional counter and a G-M gross counting system. The Water Truck carries a 946-litre water supply; it also tows a trailer which is used primarily for personnel decontamination. The Decon Traller is equipped with a water heater, shnwer and sink to clean up team members who have been working at the accident scene. Personnel monttoring instruments are avallable to determine the degree of contamination both before and after cleanup. Supplies of fresh protective clothing and equipment are stored near the exit door.

The Water Truck also provides a storage area and issue point for a wide array of portable survey instruments, air samplers, and other health and safety equipment. Yre-packaged (boxes and sultcases) monitoring instruments are also stored in the Water Truck. These consist of tritium monitors, SPARK units (Special P:arpose Accident Response Kiti and a urinalysis kit. Each of these packages van be hand-carrled by individual Health Physlcists to an accident scene if the complete mobile lab is not required.

The Mobile Laboratory was conceived with versatility and ease of movenent as a design goal. It can travel over the highways; the four units all fit in one Air Force $\mathrm{C}-14 \mathrm{l}$ transport alrcraft (Fig. C-2); the units can be forklifted and can be slung from helicopters; and the generator and air-conditioniag system can be unbolted from the truck body and operated independently of the truck.

In summary, the Hazards Control HOT SPOT Team is ready to move to an accident scene within one hour of notification. The response can be tallored to fit the clrcumstances of the accident - it ranges all the way from one individual with $=$ suitcase of specialized instruments to the entire Hazards Control Team with the complete Mobile Laboratory. Although designed primarily to assist the DOD in nuclear weapon accidents, the Hazards Control HOT SPOT response capability could be made available for any accldent involving the dispersal of radioactivity. 


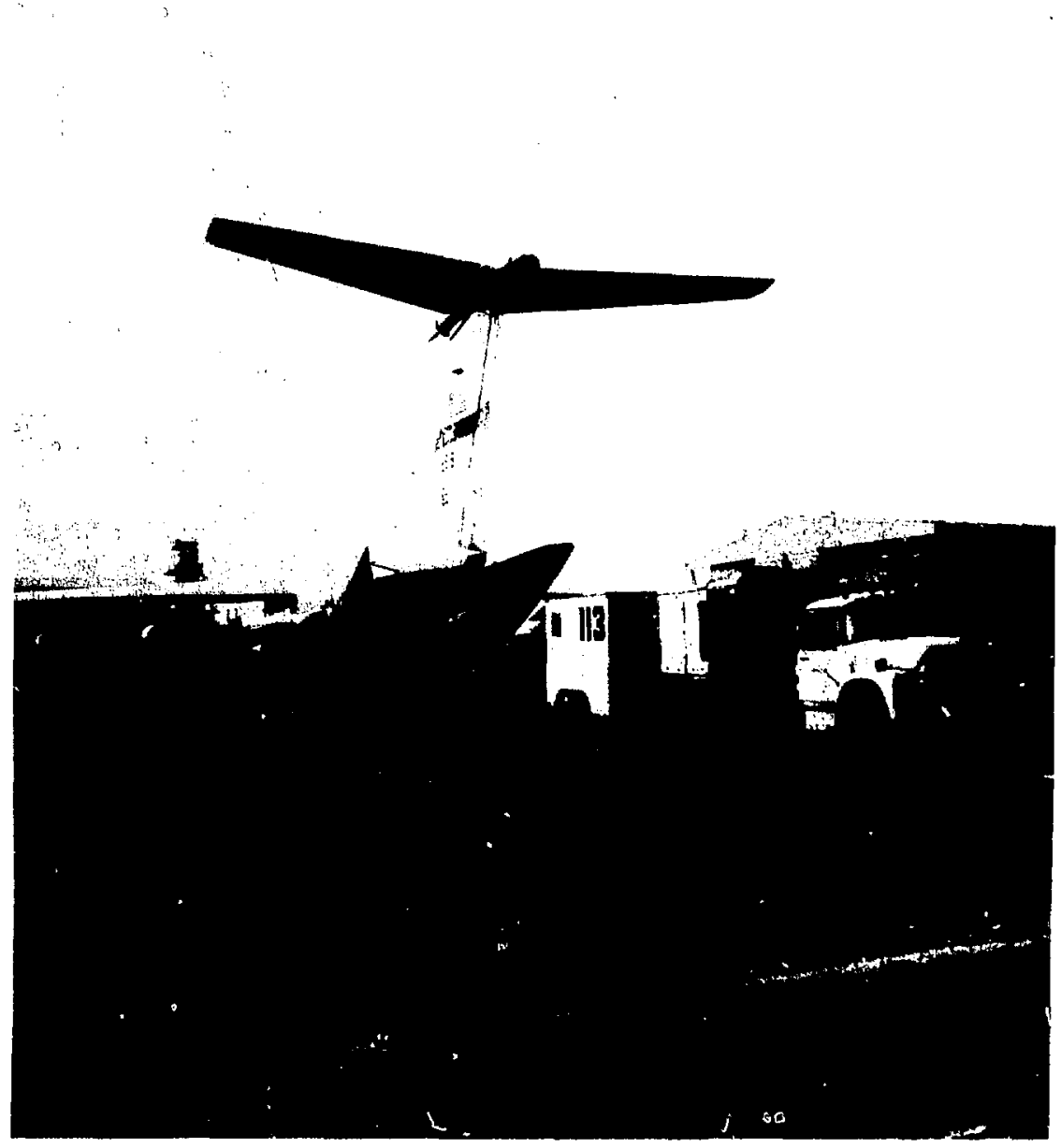

Fig. C-2. Mobile Laboratory being loaded into C-141 transport plane.

$-26-$ 
A physisal description of the Mobile Laboratory is as follows:

$\frac{\text { Dimenglons (m) }}{\text { Length W1dth Height }} \begin{gathered}\text { Shipping } \\ \text { volume }\left(\mathrm{m}^{3}\right)\end{gathered} \begin{gathered}\text { Loaded } \\ \text { welght (kg) }\end{gathered}$

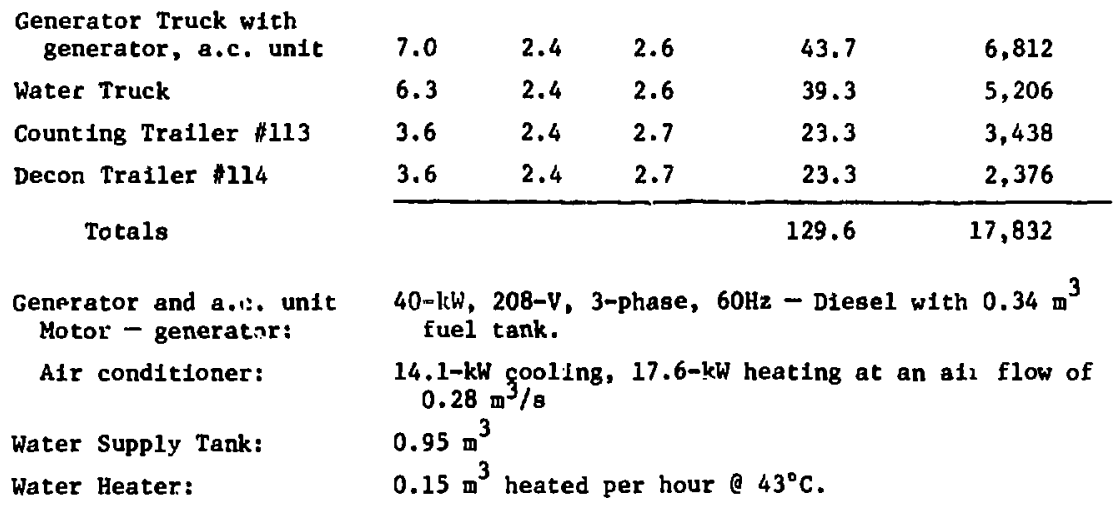




\section{Appendix D \\ Atmospheric Release Advisory Capability (ARAC)}




\title{
ATMOSPHERIC RELEASE ADVISORY CAPABILITY (ARAC): DEVELOPMENT AND PLANS FOR IMPLEMENTATION
}

\begin{abstract}
The Atmospheric Release Advisory Capability (ARAC) is an ERDA-sponsored sexvice planned for nuclear facilities which require a means of real-time prediction of the extent of health hazards that may lesult from a release of radionuclides or other toxic materials. Since 1973 when the ARAC corcept was initiated, a joint feasibility study has been conducted by Lawrence Livermore Laboratory and Savannah River Laboratory, and a proto-

type component of the system has been built and placed in operation. During the next three years plans are to implement the AFIAC service for cerlain ERDA nucleas facilities. This report is written to provide a brief description of the ARAC concept, to discuss the progress to date. to outline future plans for developing the system, and to provide potential users with the benefits, requirements, and costs involved in using the ARAC service.
\end{abstract}

\section{Introduction}

Facilities that handle radioactive materials have a paramount obligation for the protection of both their operating personnel and the public at large. In spite of a remarkable overall record of safety, the nuclear industry faces a great challenge in minimizing potential damage which could result from nuclear accidents and incidents. It must be recogn.eed that the advent of nuclear materials introduced new forms of hazard subject to technical controversy and often misunderstood by the layman. An inherent fear of the effects of radloactivity tends to exist on the part of the public, and special care is necessary to avoid undue jeopardy to the potential netional asset which nuclear energy represents, Continuation of a favorable nuclear safety record depends not only on strict adherence to standards and regu- lations, but also on extra effort at the local level to foresee any potential occurrences and to plan emergency actions.

Although the growing nuclear power industry on the whole is engaging this problem, the ERDA nuclear sites (research and production facilities) have found a speclal responsibility in this regard. Because they have been participants in the initial pioneering effort in the field and agents for an enormous part of the overall handling of nuclear materials for the nation, they have always given special emphasis to safety and accident prevention. Federal direction and assistance in matters of nuclear safety are available; nevertheless, the safety aspects of nuclear material handling must ultimately rest upon the diligent effort applied at each facility. 
In the execution of this responsibility the ERDA nuclear sites are typically faced with a number of questions such as the following:

- What health hazards to operating personnel and the public would result in the event of a nuclear accident or incident?

- More specifically, how fast and to what extent will a release of radioactive materials diffuse under a particular set of circumstances and weather conditions?

- What kind of predictive information can be derived in order to permit adequale decisions in an emergency?
- How can routine releases of radicactive materials be planned so as to minimize potential impact on the surrounding environment?

ERDA is in the process of establishing a means of as ting the management at ERDA nuclea -ites in responding to these types of questions. Under the cognizance of the DBER program, LLL has developed a centralized service to provide ERDA nuclear sites with real-time predictions of the consequences of an atmospheric release of radioactive materials. This service is called Atmospheric Release Advisory Capability (ARAC). ${ }^{1}$

\section{Purpose of ARAC}

The chief purpose of ARAC is to provide responsible site officials with estimates of the effects of atmuspheric releases of hazardous materials as rapidly and accurately as possible, ARAC would develop a series of advisories concerning emergency or routine atmospheric releases to assist the site in its planning. At the heart of the ARAC concept are the numerical models that provide real-time regional assessments based upon input data from the site. These models yary in complexity from a single-trajectory model to an interfaced set of advanced regional transport and diffusion models covering the distance range of $\sim 10-100 \mathrm{~km}$. The models, combined with other stateof-the-art technology for dose conversion and data handling and communication, permit a great] y improved but economical means for prediciting the effects of releases of toxic materials of any sort.
While the primary function of ARAC is to assist a site in emergency response, there are additional more routine uses intended for this service, Some examples are:

- Calculate and maintain an inventory of radioactivity in the source.

- Maintain an updated inventory of routine releases and their location in the environment.

- Calculate doses from routine operations.

- Perform sensitivity studies to ascertain changes in pathway drives that determine the biological impact possible from changes in site operations and in site location for projected facilities.

For a particular ERDA site, the ARAC concept would offer the following advantages:

- Predictive capability based on a local automated system. The ARAC site 
equipment would provide the means for locaily applying atmospheric modeling techniques for close-in distances $(-5 \mathrm{~km})$.

Links with advanced state-of - the-art predictive capability. The ARAC central facility would provide the results of newly developed regional modeling techniques and dose conversion data in real timc. Access to large-scale computer systems and modern efficient data handling would permit countermeasure planning based on information products not readily available at an individual site.

- Emergency backup liniss. In the event of an accidental release, countermeasure planning could also be conducted away irom the local site. Graphic display of data at several remote locations would permit coordination and alteriative options.
- Minimal costs. The centralized basis of ARAC would prernit economies not practicul for individual sites.

Whon implemented, the ARAC would support the present ERIJA role for assistanco to operating nucledr sites in several important ways. These include, but are not limited to, the following:

- The quality of information and radiological advisorites fcom l:Rl.)A would be improved due to the availability of realtime dat a and regional information.

- The predicted off-site radiulogical effects would include transient regional transport processes.

- Any off-site countermeasures and postemergency cleanup operations would have a basis for iterative improvement as zctual ractiological information is received.

- ARAC would serve as a focal point to develop future improvements in the assistance and advisories provided by ERDA. 
Appendix E

Personnel List

$-33-$ 
HSX-75

PERSONNEL LIST

\section{PLAYERS}

\begin{tabular}{|c|c|c|}
\hline Philip E. Coyle & - & Senior Scientific Advisor \\
\hline Joseph F. Tinney & - & ERDA Hdq. Rep. \\
\hline Lawrence G. MInnt is & - & Army Depot Commander (DNA/LLL, LTC) \\
\hline Charles Vetth & - & Atmospheric Release Advisory Capability \\
\hline David S. Myers & - & Senior Health Phyalelet \\
\hline Delbert F. Cruff & - & Stockp1le Weapon Des.1gner \\
\hline Sonald Martinell & - & Arming, Fusing and Firing (Sandia) \\
\hline W11l lam Har cmar. & - & Bus1ness Services \\
\hline revid Leary & - & Security \\
\hline koss L. Wilson & - & Coordinater \\
\hline John Clatworthy & - & Coordinator \\
\hline Wade Patterson & - & Health Physicist - KOT SPOT Team \\
\hline Jordan Powe11 & - & Health Physiclst - HOT SPOT Team \\
\hline Timothy Madden & - & Health and Safety Tech - HOT SPOT Team \\
\hline Carl Sindbeck & - & Health and Safety Tech - HOT SPOT Team \\
\hline Jarry Anderson & - & Mob1le Laboratory - HOT SPOT Team \\
\hline Thomas Jenkins & - & Mob1le Laboratory - HOT SPOT Team \\
\hline Thomas Jones & - & Arming, Fusing and Firing (Sandia) \\
\hline Frank Murar & - & Arming, Fusing and Firing (Sandla) \\
\hline Kendall R. Ptterson & - & Atmospheric Release Advisory Capabilicy \\
\hline John E. Hogan & - & 548th EODC (Capt) \\
\hline John E. McCray & - & 34 th EOD (Capt) \\
\hline Dennis C. Campbe11 & - & 34 th EOD (Sfe) \\
\hline George R. Perry & - & 34th EOD (SEg) \\
\hline James R. Wazford & - & 34th EOD (Ssg) \\
\hline Darrel L. Perry & - & 34 th EOD $(S p-5)$ \\
\hline ?. E. MacBain & - & LLL Fire Department \\
\hline
\end{tabular}

2. UMPIRES

Joseph F. Tinney
Nathan D. Benedict
Colin Campbell
* Dual Role - Player/Uinpire

$\begin{array}{ll}- & \text { Sentor Umpire } \\ - & \text { EOD Umpire } \\ \text { - } & \text { EOD Umpire }\end{array}$ 
Melton H. Chew

George Mackanic

Rice T. Trolan

John E. Hogan*

3. SUPPORT

Ricahrd P. Guarient 1

Clarence $\mathrm{S}$. Myers

James A. Loftis

Joseph Magana

John Walden

Jim Evers

Rgyinond Gunnich

William Thayer

Wayne Conner

Cecil Spencer

Richard Servas

James Caywood

Howard Alford

Hans Benhard

4. OFFICIAL VISITORS

otho V. Kinsley, LTC

Kenneth C. Zhan, LTC

Manley $k$. Wu

Donald E. Blvings

Howard Stinson

Mack Viars

Willtam E. Trent, LTC

Louis H. Caruso, MAJ

Stephen H, French, MAJ

John B. Culver, LCDR

James A. Peattie, CWOZ

Paul C. Kinnery, CWO3
- Mobile Laboralory/Health Phys lce limpire

- Control Umpire

- $\quad$ HOT SPOT Team Limpire

- EOD Umpire

- Safety Support Team Leader - Site 300

- Asst. Chief LLL Fire Lepartmenl:

- Health and Safety Technician

- Chemistry

- Chemistry

- Chemistry

- Chemistry

- Chemistry

- Site 300, W-DLvision Coordinator

- Site 300, Building 836

- Tech. Info, Dept. (Photo)

- Tecĭ. info. Dept. (Photo)

- Tech, Info. Dept. (Photo)

- Tech. Info. Dept. (Pholo)

- DNA/LLL

- DNA/LLL

- ERDA/SAN off :ca

- Hdq. 6th Army, Presidio San Francisco

- ERDA/SAN Office

- G-3/DPT, Fort ord, California

- Fort Ord, California

- Chemical office, Fort Ord, Caliiornia

- Hdq, 6th Army, Presidio of San Francisco

- Naval Weapons Station, Concord, California

- Naval Weapons Station, Concord, California

- Naval Weapons Station, Concord, California 
Appendix F

Chronology of Events 


\section{CHRONOLOGY OF EVENTS}

$\mathrm{HSX}-75$

$\underline{\text { TIME }}$

0730 Exerctse initiated by G. Mackantc. Call made to J. Tomlinson in the Police Commitications Center (Message 1).

0735 Ross Wilson briefed the Emergency Dispatcher at the Fire Dspartment regarding HOT SPOT Team call out (1.e., use of Message 3).

0736 G. Mackanic recelved call from LLI Senlor Sclentific Advisur (Phil Coyle). Nackanlc delivered Message 2. Clarification discussion followed. Call completed at 0740 .

0741 Emergency Dispatcher (Debble Joseph) received call from the Police Communications Center to activate the HOT. SPOT Team. (Myers, Patterson, Clatworthy and Beason responded on the telephone to the first call made over the radio page system - telephone follow-up started).

0753 Ross Wilson reported to the ALERT Center.

0755 Wade Patterson (Acting Senior Health Physicłst) advised the ALERT Center that he was at the Laboratory and requested instructions. He was advised to remain at Bullding 253 for the present.

0800 Emergency Dispatcher called the ALERT Center and advised that telephone follow-up with HOT SPOT Team difficult; team members enroute to work.

0803 ALERT Center attempted to locate Senior Scientific Advisor to advise that Center was operational (radio page used).

0806 ALERT Center advised by J. Clatworthy that organization of the HOT SPOT Team was proceeding. ALERT Center requested David Myers, Sentor Health Physicist, to report to the Center.

0815 Senior Scientific Advisor (SSA) contacted at the Police Communications Center and advised that the ALERT Center was operational. SSA talked to Sentor Health Physicist and advised contact with ARAC to get estimate of downwind radiation levels. SSA advised ALERT Center to contact Arming, Fusing and Firing Specialist at Sandia (Message 4). 
0816 Transpurtation Motor Pool Drivers, N. Steele and W. Burtenhouse, arrived at Hazards Control (Building 253) to orlve HOT SPOT trucks to Site 300. Trailers ready to depart.

0830 AII members of the ALERT staff were assembled in the ALERT Center to be brjefed by P. Coyle (SSA). Members present: C. Veith and K. Peterson (ARAC)., K. W1lson and J. Clatworthy (Field Coord.) D. Myers and W. Patterson (Health Physics), D. Cruff (Stockpiled Weapun Design), F. Murar, T. Jones, and R. Martinell (AF\&F/SLL), W. Hartman (Business Services) and David Leary (Security).

0836 ERDA EOC (G. Mackanic) advised SSA on detalls of the accidert (Message 5).

0850 Message 5A called from Presidio San Francisco (G. Mackanic) to SSA chat helicopter support was available to transport initial team and requesting further instructions.

0855 Message 6 from JNACC (G. Mackanic) to SSA that C-.141 available to transport HOT SPOT trailers From Travis AFB to Reno, Nevada.

0913 SSA called Presidio San Francisco (G. Mackanic) to advise helicopter to pick up initial team at Livermore Airport at 0945 hours.

0915 SSA called Col, Brown at Travis AFB referencing the JNACC arrangements. Coyle stated that LLL HOT SPOT trucks and trailers would depart Livermore at 0930 hours and arrive Travis at 1030 hours. ETD from Travis of $\mathrm{C}-141$ was 1100 hours.

0927 SSA called Col. Hawlk, Co at the Army Depot, to provide him with details of LLL capabilitles and travel arrangements.

0930 HOT SPOT trucks and trailers departed LLL for Travis AFB (actually will go to Site 300 ).

0933 SSA placed a call to General Bratton at DMA to advise him of LLL response status and ETA's of LLL components.

0950 Advance team consisting of P. Coyle (SSA), D. Cruff (Weapon Design), R. Martinel1 (SLL/AF\&F), J. Clatworthy (Field Coordinator) and J. Tinney (ERDA representative) departed LLL for the accident site. 
1040 Initial team arrived on site.

1043 Initial team briefed by the military commander, Maj. Gen. Minnich.

1055 HOT SPOT trucks and trailers arrived on site.

1115 Trailers 113 and 114 were operational.

1130 Health Physics personnel dressed out and entered exclusion area to take soil samples (W. Patterson, T. Madden).

1135 Counting equipment in the mobile lab checked out; electronics okay.

1150 Fire Department personnel completed decontamination of personnel and equipment. Released from the exercise.

1200 EOD action on the damaged weapon at the decision stage; $D$. Cruff advising.

1230 Health Physics personnel returned with samples for laboratory analysis.

1305 EOD operations completed. Warhead returneo wo shipping container and prepared for shipment to rework facility.

1320 Visitors arrived and were briefed.

1430 Laboratory analysis provided Indication of Health Physics problems. HeaIth Physics Group advised General Minnich on the problems assoclated with contamination.

1530 Exercise terminated. 
Appendix G

Critique Comments

$-41-$ 
CRITIQUE COMMENTS : ARMY ON-SCENE COMMANDER

A. GENERAL COMRENTS.

1. Downwind contamination is the major problem area to emerge from the HSX. The Sixth Army Nuclear Accident/Incldent Control Plan (NAICP) was used as the basis for simulating military reactions in the accident scenario. The plan has no provision for off-site contamination. If the contamination is great enough downwind to constitute a health problem, then several steps must be taken:

a. Gather all avallable meteorological data and cloud information; calculate most probable area of contamination; decide on saf aty factors; decide on "af fected" area of concern.

b. Evacuate the area if the cloud hasn't passed.

c. Monitor the area.

d. Monitor personnel.

e. Control access to and from the area.

f. Decontaminate:

(1) Personnel.

(2) Personal and real property.

These operations can require many personnel and much equipment, and the affected area can cover hundreds of square kllometers. The affected area in this problem was only 40 square kllometers, due to spectal constraints of the problem. However, estimates made in the absence of the particularized information of the exercise will define a much larger area. As a consequence, military planners should comit large numbers of security personnel. They will, In addition, be required to isolate the contaminated area around the accident site and to control classifled materlals in and around the site/CP over a period of many days.

2. The major subsei of problens associated with of f-post dewawind contamination is jurisdicilon. The military cannot take the actlons described above (except under martlal law) without, at the least, the concurrence of local and state officlals. Speaking from an ignorance of what agreements are in effect, I can oniy emphasize tiat such agreements should exist; the incumbents should confer; the agreements should be made known (the HSX participants didn't know what they might be). 


\section{Clearances:}

a I regard cross-agency security slearances as potential stumbling blocks in the path of progress. They are supremely Important, and $I$ do not wish these comments to reduce our caution.

b. In the case where ERDA is supporting DOD, most ERDA parti:ipants will have the requisite clearances. Afflrming those clearances to DOD is the obstacle I foresee to fieting ERDA people on-site and functioning. Unfortunately, DOD doesn't recognize ERDA badges, and teletype links may not be avillable. 1 don't know what procedures are established, and feel that this area should be reviewed by JNACC.

c. In those cases where DOD supports ERDA, the mass of DOD participants will not be cleared for Restricted Data (nor even for materlal corresponding to Confidential or Secret), and the on-site control of materials and Information may well bog down the operation. Again, JNACC should review.

d. The wheels of security clearance grind exceedingly slow. Again, the importance of sicurity is paramount, but in the general case, provision must be made (ahead of $!$ ime, in a nonemergency environment) for greasing the wheels when an emergency occurs.

4. Prepared PIO releases in USASIX NAICP (15 Nov 73 edition) do not cover the situation of an on-post accident with off.-site contamination.

5. I suggest that the Nuclear Accident Incident Control officer (NAICO) be made responsible for formulating and circulating an emergenry safety procedure for the site during control operations. A second accident or incident during control and cleanup would be extremely disruptive and knowledge of hazards and corrective actlons by personnel on-scene would ameliorate the disruptive effects.

6. Recommend that the On-Scene Commander be directed to provide for (in concert with ERDA) the disposition of contaminated materials.

7. I feel, as a result of this exercise, that the primary functions of the On-Scene Commander should correspond to the dctions of a triage officer in a medical emergency. Life-threatening situations should recelve first priority; consideration of lesser threats to life (such as $\mathrm{Pu}$ contamination after cloud passage) should bo deferred unt1l the accldent situation is stabilized. Outside pressures for information or action should be firmly resisted and prio: 1ties established. The ARG staff in this exercise very smoothly led me to do these things (as the umpires had hoped). 
8. The 34 th EOD team was superb. LLL personnel were visibly (and volubly) impressed with their expertise and professionalism. The exercise served a valuable purpose 1r exposing LLL to their procedures and capabilities and provided the Laboratory a valuable insight fals how they can best interface with EOD in an actual emergency. By the same token, EOD personnel had theit first opportunity to talk to the designers of the weapons upon which they work and (for this team, at least) to realize the breadth of assistance avallable to them if they need it. For this reason alone, future foint exercises should be encouraged.

\section{B. LABORATORY OPERATIONS}

1. It is very important that the On-Scene Commander (I'11 call him the NAICO for shorthand purposes) be Impressed with the willingness of the ARG to help him solve his problem. Consequently, SSAs should be firmly impressed (and retrained if necessary) with the necessity of exuding an aura of confidence, helpfulness, and competence as they arrive on-scene. This was done in the HSX. As a related point, the ARG should be organized so that the minimum number of personnel physically address the NAICO. The recommendation serves two purposes:

a. The SSA/ERDA Rep should be the experts tc whom the NAICo turns, and Internal disagreements within the ARG are not the NAICO's concern.

b. NAICO has a span-of-control problem already.

2. The advance party should probably depart as soon as assembled. Their generalized expertise is more than is avallable on-site, and they can contribute to the solution of the problem without detalled knowledge prior to their arrival. SHP's advice on the off-site contamination hazard was most valuable. For instance, I tried to push the ARG staff into reccmmending a teclaration of martial law, but cooler heads prevailed, and I was thwarted.

3. A possible shortcoming of the exercise was in my dual role as NAICo/Umpire. Knowing as much about the problein as I did, I perhaps led the ARG Into consideration of problems that another NAICO might not have brought up. As a positive recommendation for future exercises, suggest that a military type be brought on board as a NAICO player with no prlor knowledge.

4. The message about plume height was passed to me, but didn't reach ARAC because nobody asked me about eyewitness accounts, or if further Information was avallable. 
5. Because of the large number of individual vehicles located at Site 300 , it didn't look much like an accident site, but rather like an exercise site. Better ccatrol of vehicles and personnel for future problems will add more realism.

6. The time pressure which we introduced into the problem was unrealis.tic. However, it partially compensated for the pressure from outside agencies (JNACC, ERDA, etc.), which would have been present in a real situation. One of the most Important things the NAICO/ARG can do is to set priorities for their action items and take care of the right things first. I was very impressed by the smcoth way that priorttles were established.

7. I suggest that ARG staff should have prepared ahead of time several generalized contingency plans with fill-in blanks for the following items:

a. Emergency operating safety procedure (per Tinney).

b. Disposition of contaminated materials and debris.

c. Disposition of contaminated classified items.

d. ARG chain-of-command.

8. Clearances and Security:

a. I regard this area as a potential stumbling block in the path of progress. It is supremely important, and I do not wish thioe comments to detract from that importance.

b. In the case where ERDA is supporting DOD, most ERDA participants will have the requisite clearances. Affirming those clearances to DOD is the obstacle I foresee to getting ERDA people on-site and functioning. Unfortunately, DOD doesn't recognize ERDA badges, and teletype links may not be avallable. I don't know what procedures are established, and feel that this area should be reviewed by JNACC.

c. In those cases where DOD supports ERDA, the mass of DOD participants will not be cleared for Restricted Data (nor even for material corresponding to Confidential or Secret), and tie on-site control or materials and information may well bog down the operation. Again, JNACC should review.

d. The wheels of security clearance grind exceedingly slow. Again, the importance of security is paramount, but in the general case, provision must be made (ahead of time, in a nonemergency environment) for greasing the wheels when an emergency occurs. 
My participation in the alert exercise started at 0745, Tuesday, September 23, 1975, by a phone call from the LLL Polfce Communications Center. My instructions were to "call Phil Coyle on X4211" which I did Immediately. During the conversation with PhIl, my radio page signaled and gave a message that I didn't understand as Phil was talking at the time. The reception was clear enough to understand if I had not been disturbed by the conversation on the telephone.

Phil told me what he knew and told me to call him back when the Alert Communications Center in Bullding 111 was in operation. At 0820, I called Phil at the Police Communicationg Center where he had gone and told him the Alert Communications Center was open.

When I arrived at the Alert Communications Center, I asked Betty Davis to get out the microfilm reel on the $W-70$ and put 1 on the viewer. No further use was made of the microf $11 \mathrm{~m}$, and $1 \mathrm{t}$ was returned to the repository after the advance party left the Center for S1te 300 .

During the discusstons in the Communications Center, it was decided that I was the only avallable weapon designer, and would participate in the exerciae In that capacity. I then want bick to my office to find a substitute to act for me in the Communicatsons Center while I was in transit to the scene of the accident. The first qualified person I could locate was a former W-70 weapons design engineer, Bill Bachelder; however, Blll fid not on the HOT SPOT roster and would not have been able to travel with the same convenlence that a HOT SPOT member would; 1.e., If the accident were out of the conus.

I took a briefcase with the classifled HOT SPOT flle on the W-70 to Si:e 300 .

I was In the party that was brlefed by General Minnich on the accident and what had been done to that time. During the briefing, a starement was made that the EOD captain wanted to consult with the weapon designers and as we were leaving for the bunker, an Anny man stated to the General clat they were preparing the weapon for a rendering-safe procedure and asked permission to start the safing procedures. I sald that we would like to survey the situation before safing was authorized and the General agreed, but pinted out that the decision to safe or not to safe rested with him - not us. 
We sinulated "dressing out" for work associated with a damaged nurlear warhead and examined the warhead that was involved in the accident. We, the EOD captain and the weapon designers, agreed to proceed with the EOD procedures and cut open the warhead's aluminum skin to ascertain the condition of the components in the damaged area. After this was done, we again agreed to Immobilize the damaged components and to prepare the warhead for shipment.

This concluded my participation in the exercise. I have a few thoughts on the operation and will attempt to describe them here.

First, I think the whole exercise went very well. The parts played by the participants were sincere and realistic from the "General" on down to the rad safe monitors. In my role as a weapon designer, I feel that we rushed a 11ttle too fast. In a real situation, I would prefer to sit down with the EOD captain and discuss every detail that he had experienced up to the time of my arrival. I would have spent more tfme looking at the EOD manual and the englneering drawings that we had in our possession. Since the warhead had been moved some distance from the accldent location, there was really no need to work as fast as possibje to prepare it fur shipment.

Another comment: I have never worked witi an EOD taam berore and was pleasantly surprised to find them very competent and cooperative. They were very well trained and made very good use of some falrly crude tools. They in turn sald that they had never worked with weapon designers before and appreciated our cooperative attitude.

\section{CRITIQUE CONMENTS: SENIOR HEALTH PHYSICIST}

In general, I felt the exerclse was very usoful for the Hasards Control members of the ALERT Team. A major benefit was that team members thoroughly reviewed procedures and equipment prior to the exercise. There are a few specific comments that I would like to make, some of which might contribute to future exercises. These comments alse reflect Input from $W$. Patserson and J. Powel1.

1. In our view, the overall Hazards Control response was excellent, and we have no comments or suggestions for improving that.

2. Initially, there was some confusion regarding the information that ARAC gave us. The problem stemed from a misunderstandirig of the units on some of the data that they generated. Th1s confusion has been resolved in discussions with Ken Peterson. 
3. The exercise emphasized the importance of pre-planning the prompt actions that any installation must cake if they are to effectively prevent oxpogure to individuals downwind from the passage o: a cloud. By the time we were able to supp 1 y them with suggested arias of evacuation and traffic control, it would have been too late to actively implement our suggestions. As I mentioned in the critique, I feel it would be useful if such installations, perhaps based on iniormation supplied by ARAC, would have on hand tentative evacuation or notffication procedures in the eveni of serlous accidents.

4. As I also mentioned in the critique, the scenar o forced us to tearrange our priorities. In the real situation our first priority would not have been to charge in and map out the areas of ccutamination, but rather to make s"re that victims and areas outside the known contaminared area were handled and menitozés uppropriately.

Also, interacting with state or federal agencies regarding necessury off-site actions to control and assess exposurf and to reduce the spread of contamination would be of primary importance. Perhaps some of these health physics considerati ns could be handled in some form of classroom exercise where the health Physicists were presented a series of problems on paper, about which they had to make decisions and recommendations.

5. I think it would be useful to coordinate the next exerctse with a real military exercise, perhaps one of thor a at Fort Ord.

\section{CRITIQUE COMMENTS: WEAPONS UMPIRE}

As an umpire, : observed the EOD portion of the HOT SPOT Exercise which included actions performed by an Ariay EOD team and LLL/SLL HOT SPOT team members in response to a hypothetical accident situation.

Due to a necessarily short schedile, some short cuts were necessary and certain actions," their nature time-consuming, were "talked through to completion" wan che umpires .oncurrence.

It became evident early in the exercise that this EOD team was very knowledgeable concirning the weapons involved as several inaccuracies of construction and violations of existing military safety rules were immediately noted and commented upon.

Clean up and desensitizing of scattered high explosive (in this case, mock) was accomplished to the point that a total sweep of the area wats required 
which would have involved excessive time and people. At this point, this activity was terminated by umpire decision.

Al1 decistons regarding actions to be performed on the weapon by the EOD team, Including the decision that further technical advice was required, were correct and well thought through.

After the arrival of the LLL weapons engineer and the Sandia fusing and firing engineer, actions requiring $x$-ray and special tools (bore-scope) were decided upon, and were assumed accomplished but Indeterminate by the umpire.

Cutting into the weapon was actually accomplished, and subsequent dectsions regarding immobilization of componente and preparation for shipment were made after which the exercise was terminated.

Having participated in real accident situations, I was able to make comparisions and found that even though staged and foreshortener. this portion of the exercise had a "real" feel about $1 t$ and was a valid check of the EOD team as well as its interactions with the Laboratory team members, all of whom acted in a knowledgeable, professional manner.

\section{CRITIQUE COMMENTS: HEALTH PHYSICS UMPIRE}

In order to develop a meaningful evaluation of the health physics operations assoclated with the burned nuclear weapon, it was necessary to develop some physical alds. The ground deposftion of plutonium was represented by a pattern of wooden stakes placed at: varlous locations downwind from the accident site. Each stake was labeled with readings in counts per minute. The readings approximated actual count rates on a PRM-5 with a FIDLER probe set to measure the $17-\mathrm{keV}$ photon frov ${ }^{239} \mathrm{Pu}$ or the $60-\mathrm{keV}$ photon from $241_{\mathrm{Am}}$. In addition, soll samples were prepared for sixteen locations using a Pu-Oy mix. Each doubly encapsulated soil sumple represented the contaminated sofl collected in a $100 \mathrm{~cm}^{2}$ area $2 \mathrm{~cm}$ deep.

When the Senior Health Physicist arrived with the inftial HOT SPOT Team, he was brtefed on the accident and the physical atds whtch were emplaced to assist him in assessing the radiological problems. Earlfer, personnel from the 34th EOD had made a cursory survey of the lmmediate accident site. This fnformation was also soade avallable to the Senior Health Physicist. Finaliy, the LLL Atmospheric Release Advisory Capability provided a projected 
pattern of hazardous material which included surface deposition, as well as air concentrations up to $100 \mathrm{~km}$ downwind.

When the main HOT SPOT Team arrived, the Senior Health Physicist Instructed his group in the following:

- Proper personnel protection to be used In the exclusion area.

- Type of ground survey to be made with the FIDLER instruments in order to get a contour of the ground deposition of fissile material (see F1g. G-1).

- Analysia to be made of the soll samples in the Mobile Laboratory to develop a defintefve evaluation of hazardous levels of $\mathrm{Pu}$. As the exercise progressed and the radiation problems were evaluated, the Senior Health Physicist made recommendations to the Sentor Scientific Advisor regarding the on-site problems for control and cleanup of the contamination. Th1s was based on the surface deposition contour map developed by the team. Additionally, he was able to use the ARAC fallout plot and provide advice regarding the maximum off-site hazard to the general population.

The HOT SPOT Mobile Laboratory equipment operated effectively in counting the soll samples. However, it was noted that the counting equipment should be configured to count samples of higher radioactivity levels. It appears that samples greater than $10 \mathrm{mg}$ of $\mathrm{Pu}$ were overloading the counting capability. The results of the sample counting were within a factor of 2 of the radioactivity in each sample.

Periodic updates of the ARAC plots would have been useful at the exerctsa site.

In general, the actions and recomendations made by the health physics participants were appropriate for the information made available.

The Army EOD personnel which I observed adhered to good radiological safety procedures. Personnel protection was good. More current radiation instrumentalion would have been useful to them.

\section{CRITIQUE COMENTS: FIELD COORDINATOR}

1. Comment: It would appear highly advantageous to be able to maintain in the ALERT Operations Center, certain important elements of information concerning an accident/incldent which necessitates an ALERT response. This would provide continuity in the event certain key people have to leave the ALERT Center, afford readily avallable information for response to jnquiries, and provide an almost instantaneous briefing for new arrivals to the ALERT Center. 


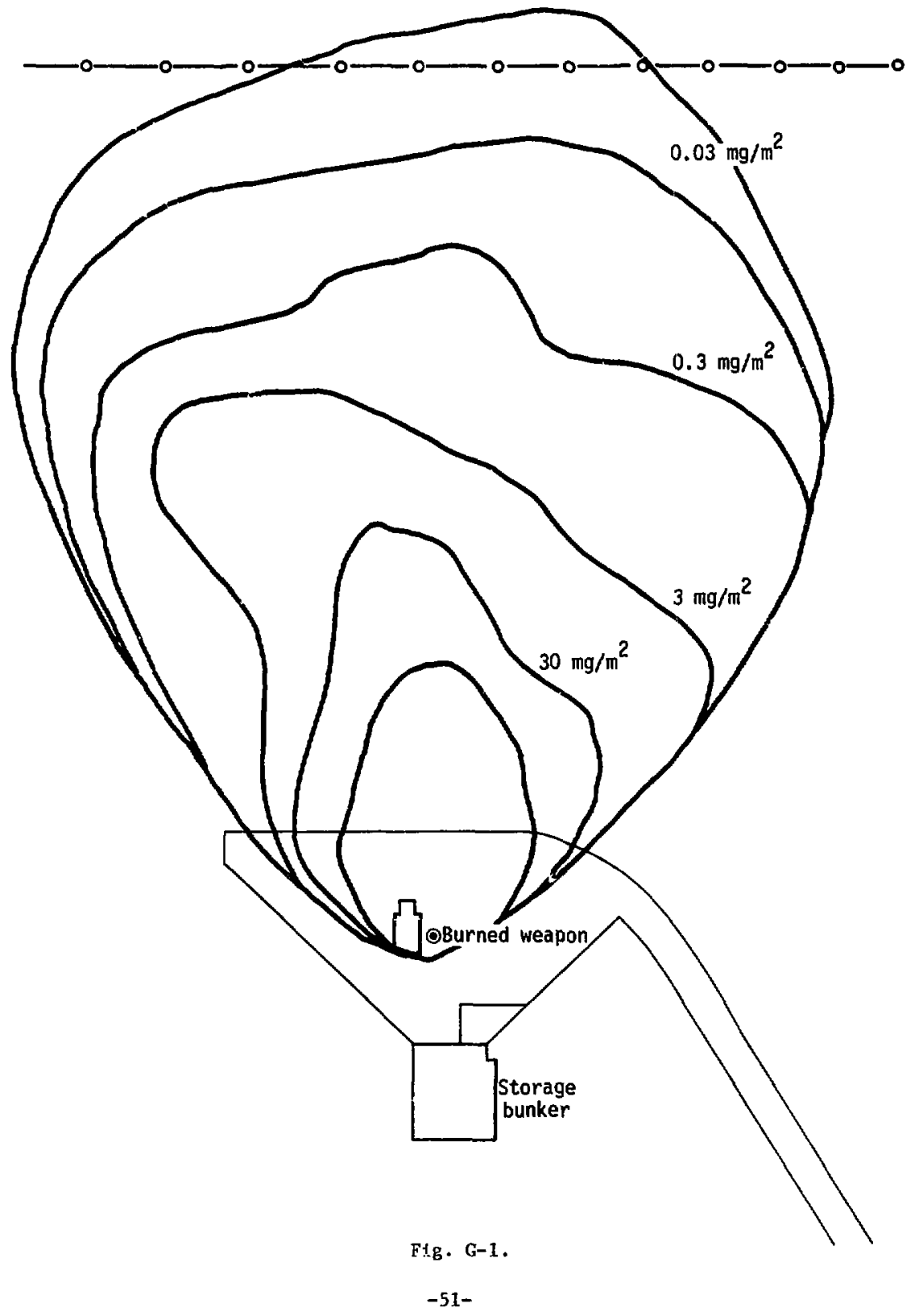


Recommendation: Provide status boards to be mounted on one of the walls of the ALERT Operations Center, which would piovide a place to record essential accident/incldent related data. Boards should have a key and/or format which outlines essential information, and should be covered in plastlc or lucite so Information can be written and then changed, updated, or removed as necessary.

2. Comment: It would appear that the Fleld Coordinator could be required to temporartly leave the close proximity of the accident/Incident scene in order to coordinate some aspect of the field operations. In this circumstance, communications with the Senior Scientific Advisor and/or HOT SPOT/Warm Spot Team Leader would be essential.

Recommendation: Two or three 2-way radios should be provided for the Field Coordinator's use. These radios should be on a different frequency than the HOT SPOT and/or Warm Spot Team radios. 